Pak. j. sci. ind. res. Ser. A: phys. sci. 201255 (2) 105-111

\title{
Impact of Sewage of Rawalpindi/Islamabad on Water Quality of Soan River with Respect to Biological/Chemical Oxygen Demand
}

\author{
Younas Kalim*, Muhammad Ishaq Ali Khan and Hajra Masood \\ PCSIR - National Physical \& Standards Laboratory, 16-H/9, Islamabad, Pakistan \\ (received January 1, 2010; revised May 3, 2011; accepted May 5, 2011)
}

\begin{abstract}
Study was conducted to investigate water pollution of Soan River. It was characterized as; mean $\mathrm{pH}$ value $7.90 \pm 0.01$, TSS $1.44 \pm 0.29 \mathrm{ppm}$, TDS $169.60 \pm 2.87 \mathrm{ppm}, \mathrm{BOD} 10.00 \pm 1.43 \mathrm{ppm}$ and COD $12.10 \pm 0.37 \mathrm{ppm}$ at 500 meter upstream before confluence of Leh Nullah. After receiving Leh Nullah waste its $\mathrm{pH}$ value decreased while BOD, COD, TSS and TDS contents increased. Comparison with the National Environmental Quality Standards (NEQS) for municipal and liquid industrial effluents into inland water was also discussed. High values of BOD in Leh Nullah pollution indicate an alarming sign for aquatic life of the Soan River.
\end{abstract}

Keywords: sewage, water pollution, BOD, COD, Soan River, aquatic life

\section{Introduction}

Soan is the main river running through Soan Valley. It was a river of great significance in geological times, but at present, the river has become a small stream, transporting the seepage of the Soan Valley storage and floodwater. A number of natural streams are running through Islamabad. In the past only rainy water coming down from Margalla Hills was discharged through these streams. Now, sewage of Islamabad is also discharged into these streams. These streams join together to form Leh Nullah, which enters Rawalpindi near New Katarian. Islamabad generates more than 30 million gallons of wastewater per day, which is discharged ultimately into Leh Nullah through these water courses. Partial treatment is given to 5 million gallons of this wastewater occasionally by the only treatment plant located in sector I-9 (Sheikh, 1998). Sewage waste of Rawalpindi is discharged into Leh Nullah without any treatment. Leh Nullah discharges its waste into Soan River at the point of confluence, near Soan wagon stand on GT road. Soan River joins mighty Indus about $80 \mathrm{Km}$ down south. The release of raw (untreated) sewage into a lake or river causes eutrofication, resulting in a sudden increase in BOD, as the organisms (algal bloom) that feed on sewage will proliferate and use up the available dissolved oxygen in the water. Oxygen sensitive organisms, such as fish, will die (Isaac et al., 1996).

Polluted water bodies are a global issue and Pakistan is no exception. Increasing population, growing

*Author for correspondence; E-mail: ykalim@yahoo.com industrialization and increased use of land for agriculture purposes using modern methods of cultivation, all contribute to water pollution. The contamination of water bodies has three main sources:

i. Domestic sewage

ii. Industrial discharges having toxic matters, organics, acids etc.

iii. Chemical pollution in the form of pesticide and fertilizer run-offs from agricultural lands.

Pakistan generates 12.5 million tons of wet human excreta per year (about 34,370 tons/day) with 26,370 tons produced in rural areas having high population density about $65 \%$ and 8,000 tons in urban areas. $80 \%$ of rural excreta is deposited in fields. Only half of the urban excreta is disposed off in sewers. The rest is dumped at dumping sites, spread on the roadsides or put into waterways (Rizvi, 1996; PNCS, 1991). The untreated sewage water is added to the irrigation system through streams and rivers. The Rawal and Simly Lakes are worst hit by the growing urbanization in the upper catchment areas (Rizvi, 1996). In Latin America as little as $2 \%$ of sewage receives any treatment (The World Bank, 1992). In Pakistan wastewater treatment facilities are available only in Karachi and Islamabad. However these treatment plants are also under capacity. Karachi is consuming nearly 360 million gallons of water per day, out of which $80 \%$ is converted into waste. But the city has treatment facilities for 30-40 million gallons per day, the rest flows into sea untreated (Rizvi, 1996). 
Most of the industrial units are set up near water sources to meet their water requirements and discharge of effluents. According to an Asian Development Bank study, only 3\% industrial units in Pakistan treat their industrial effluents conforming to internationally accepted standards (LCCI, 2002). The industrial units discharge their effluents in watercourses without proper treatment, disturbing the quality of water and production of aquatic life. In Lahore, industrial waste of Kala Shah Kaku industrial area is drained in Deg Nullah, whereas city sewage is drained through Hudiara and other drains. An increased level of BOD and mercury was detected in Deg Nullah downstream of Kala Shah Kaku industrial area (LCCI, 2002; Ahmed and Ali, 2000). Due to extreme toxicity in Deg Nullah, a fish catch of about 400 tons, valued about 10 million rupees per annum, disappeared (LCCI, 2002). The sewage and industrial waste of Peshawar and Charsadda is also polluting the River Kabul water, threatening its use for domestic and irrigation purposes besides endangering fresh water fishery and aquatic organisms in general (van Dijk and Hussain, 1994).

In Sialkot, city sewage and chemical waste from tanneries in the city and those located along the Sambrial road are discharged in Nullahs Aik and Pulkhu, which drain all these effluents into River Chenab. Aquatic life in these Nullahs is almost vanished. Industrial effluents and sewage of Karachi is drained in Arabian Sea through Malir, Lyari and other streams. An average value of BOD and COD in these watercourses is 516 and 1640 ppm, respectively (Sajjad, 2005) whereas NEQS values are 80 and 150 ppm (NEQS, 2000).

Researchers have found that pollution has severe impacts on the quality of surface water such as river and lake waters (Kolo et al., 2010; Ajibade et al., 2008; Ahmed and Ali, 2000). Effects of industrial wastes, municipality sewage and agricultural runoff on the Karnafully River water were investigated in terms of DO, BOD and COD (Sarwar et al., 2010). The capacity of a river to support aquatic life is lowered when decomposition of pollutants reduces the amount of dissolved oxygen in water. Similarly, $\mathrm{pH}$ of the water also affects aquatic life. Unlike faecal contamination, oxygen loss does not threaten health directly, but its effects on fisheries are economically important.

In present studies, sewage effluent of Rawalpindi / Islamabad, Pakistan has been examined and its impact on Soan River water determined and discussed in comparison with NEQS for municipal/industrial effluents being discharged in surface water bodies and sewage treatment plants (NEQS, 2000). Soan River is an important water body in this area. Ground water of Rawalpindi is recharged by Rawal Dam and Soan River. So level of pollution of Soan River water directly effect the quality of ground water of the area. This study provides a baseline for future researchers to find any sort of increase or decrease of pollution effect on water quality of Soan.

\section{Materials and Methods}

Sampling. Wastewater samples were collected from twelve points / locations of Nullah Leh and Soan River during January 2008 to December 2009. Total five collections were made during this period. Detail of these sampling sites / locations is shown in Table 1 as well as in Fig.1. Grab samples (single sample collected at a specific spot at a site over a period of short interval of time) were collected in clean polyethylene (PET) bottles of $2.5 \mathrm{~L}$ capacity. Collected samples were taken to laboratory in ice box and were placed in refrigerator until analyzed.

Methods of Analysis. Collected samples were labeled properly and preserved using prescribed standard methods (Clesceri et al., 1998). pH of COD samples was adjusted to 2 by adding sulfuric acid. $\mathrm{pH}$ value was determined on site by $\mathrm{pH}$ meter Model 991301, HANNA.

Biological oxygen demand (BOD). BOD was determined by Respirometric Method 5210 D, using BOD sensor inductive stirring system, Lovibond. It is a closed system. Bacteria present in the sample consume dissolved oxygen to oxidize the organic matter. Oxygen present in the air

Table 1. Wastewater sampling points

Site Name of sampling location/site

no.

1 Leh Nullah, Katarian Bridge

2 Wastewater Old Slaughter House, near Ratta Bridge

3 City Sewage at Ratta Bridge

$4 \quad$ City Sewage at Moti Mahal

5 Wastewater Leh Nullah at Moti Mahal

6 Wastewater Leh before confluence with Soan River

7 Soan River 500 meter upstream of confluence with Leh Nullah

8 Soan River 500 meter downstream of confluence with Leh Nullah

9 Soan River near Defense Housing Society Phase-1

10 Soan River opposite to Dhaghal Village, Adiala Road

11 Soan River opposite to Jail

12 Soan River at Road Bridge near Gorakh Pur 


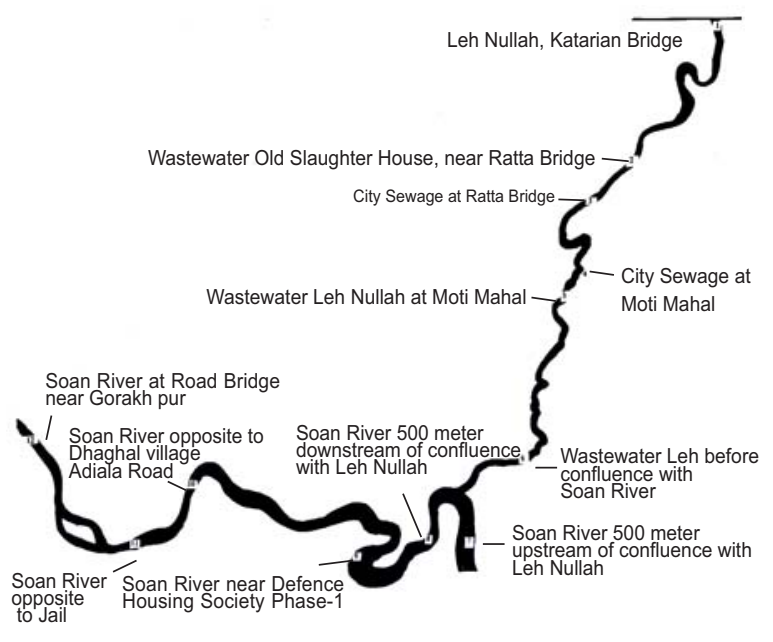

Fig. 1. Wastewater sampling points/sites

above the sample in the BOD bottle was dissolved in the sample, resulted a pressure drop in the bottle, measured by the sensor and displayed as $\mathrm{mg} / \mathrm{L}$ BOD. Carbon dioxide produced by the bacteria was removed from the system by addition of potassium hydroxide solution contained in a sealed cup in the bottle. $157 \mathrm{~mL}$ sample was taken in BOD bottles. $\mathrm{pH}$ of samples was adjusted between $6.5-7.5$, then added 5 drops of nitrification inhibitor, 2 chloro 6 (trichloro-methyl) pyridine; added a clean magnetic stirring bar to each bottle; then two drops of $45 \% \mathrm{KOH}$ solution to a dry, non-greased seal cup and inserted it into BOD bottle. Placed the Lovibond BOD Sensor on the BOD bottle and tightened carefully. Prepared bottles were placed onto the stirring unit, on the sensor. Placed the whole system in thermostatic controlled cabinet (Incubator) at $(20.0 \pm 0.5){ }^{\circ} \mathrm{C}$. After five days, the five daily values were stored in the sensor memory, noted BOD values.

Chemical oxygen demand (COD). COD was determined by Open Reflux Method 5220-B. Most types of organic matters are oxidized by a boiling mixture of chromic and sulphuric acids. A sample was refluxed / digested in a strong acid solution with a known excess amount of potassium dichromate $\left(\mathrm{K}_{2} \mathrm{Cr}_{2} \mathrm{O}_{7}\right)$. After digestion, the remaining unreduced $\mathrm{K}_{2} \mathrm{Cr}_{2} \mathrm{O}_{7}$ was titrated with ferrous ammonium sulphate to determine the amount of $\mathrm{K}_{2} \mathrm{Cr}_{2} \mathrm{O}_{7}$ consumed and the oxidizable matter was calculated in terms of oxygen equivalent.

Reagents and Glassware. Standard potassium dichromate solution, $0.25 \mathrm{~N}$; Sulphuric acid reagent: $5.5 \mathrm{~g} \mathrm{Ag}_{2} \mathrm{SO}_{4} / \mathrm{kg} \mathrm{H}_{2} \mathrm{SO}_{4}$; Ferroin indicator solution: $1.485 \mathrm{~g} 1-10$ phenanthroline monohydrate $+695 \mathrm{mg}$
$\mathrm{FeSO}_{4} \cdot 7 \mathrm{H}_{2} \mathrm{O}$ per $100 \mathrm{~mL}$ distilled water; Standard ferrous ammonium sulphate (FAS) titrant, $0.25 \mathrm{M}$; Mercuric sulphate, $\mathrm{HgSO}_{4}$, crystals or powder, and Reflux apparatus. $20 \mathrm{~mL}$ sample with $10 \mathrm{~mL}$ standard $\mathrm{K}_{2} \mathrm{Cr}_{2} \mathrm{O}_{7}$ solution, some glass beads, $0.4 \mathrm{~g} \mathrm{HgSO}_{2}$ and $30 \mathrm{~mL} \mathrm{H}_{2} \mathrm{SO}_{4} \mathrm{AgSO}_{4}$ reagent was refluxed for two hours in a refluxing flask. The mixture was cooled down and diluted to $140 \mathrm{~mL}$ by adding distilled water. To it added three drops of ferroin indicator, titrated against standard ferrous ammonium sulphate titrant. End point was blue green to reddish brown. A blank was also run.

COD as $\mathrm{mg} \mathrm{O}_{2} / \mathrm{L}=\frac{(\mathrm{A}-\mathrm{B}) \times \mathrm{M} \times 8000}{\mathrm{~mL} \text { sample }}$

Where:

$\mathrm{A}=\mathrm{mL}$ ferrous ammonium sulphate used for blank,

$\mathrm{B}=\mathrm{mL}$ ferrous ammonium sulphate used for sample,

$\mathrm{M}=$ molarity of ferrous ammonium sulphate

$8000=$ milliequivalent weight of oxygen $\times 1000 \mathrm{~mL} / \mathrm{L}$.

Total suspended solids (TSS). TSS were determined by gravimetric method, 2540 - D. Well mixed samples were filtered through pre dried and weighed PALL filters type $\mathrm{A} / \mathrm{E}$. Residue retained on the filters was dried to a constant weight at $105^{\circ} \mathrm{C}$. The increase in weight of the filter paper represented the total suspended solids.

Total dissolved solids (TDS). TDS were determined by gravimetric method 2540 - B. Well mixed samples were evaporated in pre weighed dishes and dried to constant weight in an oven at $105^{\circ} \mathrm{C}$. The increase in weight over that of the empty dishes represented the total dissolved solids.

\section{Results and Discussion}

In present studies sewage effluent of Rawalpindi/ Islamabad was examined and its effects on Soan River water were found in terms of $\mathrm{pH}$, TSS, TDS, BOD, and COD. Average results of five collections during January 2008 to December 2009 were discussed in comparison with NEQS for municipal / industrial effluents being discharged in surface water bodies (NEQS, 2000). Results are shown in Tables 2-6.

pH value. Mean $\mathrm{pH}$ value of partially treated sewage of Islamabad entering Leh Nullah at New Katarian was $7.17 \pm 0.01$. City sewage of Rawalpindi being discharged into Leh Nullah had $\mathrm{pH}$ values $7.10 \pm 0.09$ at old slaughterhouse, $7.04 \pm 0.01$ at Ratta Bridge, $6.83 \pm 0.01$ at Moti Mahal. Leh Nullah wastewater had $\mathrm{pH}$ value $6.67 \pm 0.02$ at Moti Mahal and $7.29 \pm 0.01$ just before 
joining the Soan River. Soan River water had $\mathrm{pH}$ value $7.90 \pm 0.01$ before entering Leh Nullah waste. $\mathrm{pH}$ value of Soan River water was changed between $7.30 \pm 0.01$ to $7.72 \pm 0.01$ after mixing with Leh waste. Leh Nullah wastewater lowered the $\mathrm{pH}$ of Soan water a little bit. However, $\mathrm{pH}$ values of wastewaters of city sewage, Leh Nullah and Soan River were within the NEQS limits (NEQS, 2000).

Biological oxygen demand (BOD). Partially treated city sewage of Islamabad entering Leh Nullah had BOD values $68-72 \mathrm{ppm}$ with an average value of $70.00 \pm 1.43$ ppm. Sewage waste of Rawalpindi city had high BOD values, $118-124$ with an average value of $120.00 \pm 2.34$ ppm at old slaughterhouse, 208 - 214 with an average value of $210.00 \pm 2.34 \mathrm{ppm}$ at Ratta Bridge, 298 - 302 with an average value of $300.00 \pm 1.51 \mathrm{ppm}$ at Moti Mahal. Leh Nullah wastewater had BOD 176 - 182 with an average value $180.00 \pm 2.34$ at Moti Mahal. BOD decreased as Leh Nullah emerged out of the city population. At the point just before the confluence of Leh Nullah with Soan River near Al-Shifa Eye Hospital, its average value became $80.20 \pm 2.34 \mathrm{ppm}$, which was due to aeration of water and settling of waste during its passage. Mean BOD of Soan River water was $10.00 \pm$ $1.43 \mathrm{ppm}$ at a point 500 meter upstream before mixing with Leh wastewater, therefore, the river can be classified as "Bad" river (Holden, 1970). Its average BOD value increases up to $30.00 \pm 1.52 \mathrm{ppm}$ at different points after mixing with Leh wastewater and the river becomes "very Bad" river (Holden, 1970). Sewage wastewater of Leh Nullah caused an increase in BOD of Soan River water, which is a matter of concern.

Chemical oxygen demand (COD). Chemical oxygen demand of partially treated Islamabad wastewater had an average value $75.60 \pm 1.02 \mathrm{ppm}$ before entering the Leh Nullah near New Katarian Bridge. City sewage of Rawalpindi had average COD $174.60 \pm 4.86$ to 313.44 $\pm 4.86 \mathrm{ppm}$ at different points, higher than NEQS limits (NEQS, 2000). COD of Leh Nullah waste water had decreased to $120.80 \pm 3.97 \mathrm{ppm}$ at the point just before joining the Soan River near Al-Shifa Eye Hospital. Soan River water had COD $12.10 \pm 0.37 \mathrm{ppm}$ at 500 meter upstream before confluence of Leh Nullah wastewater and increased to $32.80 \pm 0.75 \mathrm{ppm}$ at 500 meters downstream, $64.00 \pm 1.42 \mathrm{ppm}$ near Defense Housing Society, $116.00 \pm 0.89 \mathrm{ppm}$ at Dhaghal, $121.00 \pm 0.63$ ppm at Jail apposite and $72.40 \pm 1.20 \mathrm{ppm}$ at Gorakhpur. Leh Nullah wastewater caused an increase in COD of Soan River water. Increased value of COD of Soan River water near Defense Housing Society, Dhaghal

Table 2. pH Value of water samples

\begin{tabular}{|c|c|c|c|c|}
\hline $\begin{array}{l}\text { Site } \\
\text { no. }\end{array}$ & Sampling site / location & $\begin{array}{l}\text { Minimum } \mathrm{pH} \\
\text { value }\end{array}$ & $\begin{array}{l}\text { Maximum } \mathrm{pH} \\
\text { value }\end{array}$ & $\begin{array}{c}\text { Mean } \mathrm{pH} \text { value } \\
\quad \pm \mathrm{U}_{\mathrm{E}}{ }^{*}\end{array}$ \\
\hline 00 & $\begin{array}{l}\text { National Environmental Quality Standards for } \\
\text { municipal and liquid industrial effluents } \\
\text { into inland water }\end{array}$ & 6 & 9 & \\
\hline 01 & Leh Nullah, Katarian Bridge & 7.14 & 7.18 & $7.17 \pm 0.02$ \\
\hline 02 & $\begin{array}{l}\text { Wastewater old slaughter house, near } \\
\text { Ratta Bridge }\end{array}$ & 7.04 & 7.16 & $7.10 \pm 0.05$ \\
\hline 03 & City sewage at Ratta Bridge & 7.02 & 7.05 & $7.04 \pm 0.01$ \\
\hline 04 & City sewage at Moti Mahal & 6.82 & 6.85 & $6.83 \pm 0.01$ \\
\hline 05 & Wastewater Leh Nullah at Moti Mahal & 6.64 & 6.69 & $6.67 \pm 0.02$ \\
\hline 06 & $\begin{array}{l}\text { Waste water Leh before confluence with } \\
\text { Soan River }\end{array}$ & 7.27 & 7.30 & $7.29 \pm 0.01$ \\
\hline 07 & $\begin{array}{l}\text { Soan River } 500 \text { meter upstream of confluence } \\
\text { with Leh Nullah }\end{array}$ & 7.88 & 7.91 & $7.90 \pm 0.01$ \\
\hline 08 & $\begin{array}{l}\text { Soan River } 500 \text { meter downstream of } \\
\text { confluence with Leh }\end{array}$ & 7.69 & 7.73 & $7.70 \pm 0.02$ \\
\hline 09 & $\begin{array}{l}\text { Soan River near Defense Housing Society } \\
\text { Phase-1 }\end{array}$ & 7.28 & 7.31 & $7.30 \pm 0.01$ \\
\hline 10 & Soan River opposite to Dhaghal Village & 7.54 & 7.58 & $7.56 \pm 0.01$ \\
\hline 11 & Soan River opposite to Jail & 7.52 & 7.56 & $7.54 \pm 0.01$ \\
\hline 12 & Soan River at Road Bridge near Gorakh Pur & 7.70 & 7.74 & $7.72 \pm 0.01$ \\
\hline
\end{tabular}

Results are based upon five samples collected from each site.

*The reported expanded uncertainty of measurement is stated as the standard uncertainty of measurement multiplied by the coverage factor $\mathrm{k}=2$, which for a normal distribution corresponds to a coverage probability of approximately $95 \%$. 
Table 3. Total suspended solids (TSS) in water samples

\begin{tabular}{|c|c|c|c|c|}
\hline $\begin{array}{l}\text { Site } \\
\text { no. }\end{array}$ & Sampling site / location & $\begin{array}{l}\text { Minimum TSS } \\
\text { value (ppm) }\end{array}$ & $\begin{array}{l}\text { Maximum TSS } \\
\text { value (ppm) }\end{array}$ & $\begin{array}{l}\text { Mean TSS value } \\
\pm \mathrm{U}_{\mathrm{E}}^{*}\end{array}$ \\
\hline 00 & $\begin{array}{l}\text { National Environmental Quality Standards for } \\
\text { municipal and liquid industrial effluents } \\
\text { into inland water }\end{array}$ & & 200 & \\
\hline 01 & Leh Nullah, Katarian Bridge & 32 & 40 & $36.40 \pm 3.20$ \\
\hline 02 & $\begin{array}{l}\text { Wastewater old slaughter house, near } \\
\text { Ratta Bridge }\end{array}$ & 204 & 212 & $208.00 \pm 3.58$ \\
\hline 03 & City sewage at Ratta Bridge & 104 & 116 & $109.60 \pm 4.08$ \\
\hline 04 & City sewage at Moti Mahal & 240 & 252 & $245.20 \pm 5.00$ \\
\hline 05 & Waste water Leh Nullah at Moti Mahal & 126 & 136 & $132.40 \pm 5.12$ \\
\hline 06 & $\begin{array}{l}\text { Waste water Leh before confluence with } \\
\text { Soan River }\end{array}$ & 26 & 38 & $31.20 \pm 3.92$ \\
\hline 07 & $\begin{array}{l}\text { Soan River } 500 \text { meter upstream of confluence } \\
\text { with Leh Nullah }\end{array}$ & 1.0 & 1.8 & $1.44 \pm 0.29$ \\
\hline 08 & $\begin{array}{l}\text { Soan River } 500 \text { meter downstream of } \\
\text { confluence with Leh }\end{array}$ & 14 & 16 & $15.20 \pm 0.98$ \\
\hline 09 & $\begin{array}{l}\text { Soan River near Defense Housing Society } \\
\text { Phase-1 }\end{array}$ & 10 & 14 & $11.60 \pm 1.50$ \\
\hline 10 & Soan River opposite to Dhaghal Village & 04 & 06 & $5.24 \pm 0.93$ \\
\hline 11 & Soan River opposite to Jail & 10 & 12 & $11.20 \pm 0.98$ \\
\hline 12 & Soan River at Road Bridge near Gorakh Pur & 06 & 10 & $8.40 \pm 1.50$ \\
\hline
\end{tabular}

Results are based upon five samples collected from each site.

*The reported expanded uncertainty of measurement is stated as the standard uncertainty of measurement multiplied by the coverage factor $\mathrm{k}=2$, which for a normal distribution corresponds to a coverage probability of approximately $95 \%$.

Table 4. Total dissolved solids (TDS) in water samples

\begin{tabular}{|c|c|c|c|c|}
\hline $\begin{array}{l}\text { Site } \\
\text { no. }\end{array}$ & Sampling site / location & $\begin{array}{l}\text { Minimum TDS } \\
\text { value (ppm) }\end{array}$ & $\begin{array}{l}\text { Maximum TDS } \\
\text { value (ppm) }\end{array}$ & $\begin{array}{l}\text { Mean TDS value } \\
\pm \mathrm{U}_{\mathrm{E}}{ }^{*}\end{array}$ \\
\hline 00 & $\begin{array}{l}\text { National Environmental Quality Standards for } \\
\text { municipal and liquid industrial effluents } \\
\text { into inland water }\end{array}$ & & 3500 & \\
\hline 01 & Leh Nullah, Katarian Bridge & 385 & 395 & $390.00 \pm 3.72$ \\
\hline 02 & $\begin{array}{l}\text { Wastewater old slaughter house, near } \\
\text { Ratta Bridge }\end{array}$ & 500 & 516 & $510.00 \pm 5.57$ \\
\hline 03 & City sewage at Ratta Bridge & 580 & 600 & $590.00 \pm 6.32$ \\
\hline 04 & City sewage at Moti Mahal & 610 & 630 & $620.00 \pm 6.32$ \\
\hline 05 & Waste water Leh Nullah at Moti Mahal & 495 & 504 & $500.00 \pm 3.16$ \\
\hline 06 & $\begin{array}{l}\text { Waste water Leh before confluence with } \\
\text { Soan River }\end{array}$ & 550 & 553 & $550.00 \pm 2.76$ \\
\hline 07 & $\begin{array}{l}\text { Soan River } 500 \text { meter upstream of confluence } \\
\text { with Leh Nullah }\end{array}$ & 165 & 173 & $169.60 \pm 2.87$ \\
\hline 08 & $\begin{array}{l}\text { Soan River } 500 \text { meter downstream of } \\
\text { confluence with Leh }\end{array}$ & 245 & 255 & $250.00 \pm 3.41$ \\
\hline 09 & $\begin{array}{l}\text { Soan River near Defense Housing Society } \\
\text { Phase-1 }\end{array}$ & 356 & 363 & $360.00 \pm 2.56$ \\
\hline 10 & Soan River opposite to Dhaghal Village & 545 & 553 & $550.00 \pm 2.87$ \\
\hline 11 & Soan River opposite to Jail & 538 & 545 & $540.00 \pm 3.26$ \\
\hline 12 & Soan River at Road Bridge near Gorakh Pur & 520 & 530 & $525.00 \pm 3.44$ \\
\hline
\end{tabular}

Results are based upon five samples collected from each site.

*The reported expanded uncertainty of measurement is stated as the standard uncertainty of measurement multiplied by the coverage factor $\mathrm{k}=2$, which for a normal distribution corresponds to a coverage probability of approximately $95 \%$. 
Table 5. Biological oxygen demand (BOD) in water samples

\begin{tabular}{|c|c|c|c|c|}
\hline $\begin{array}{l}\text { Site } \\
\text { no. }\end{array}$ & Sampling site / location & $\begin{array}{l}\text { Minimum BOD } \\
\text { value }(\mathrm{ppm})\end{array}$ & $\begin{array}{l}\text { Maximum BOD } \\
\text { value (ppm) }\end{array}$ & $\begin{array}{l}\text { Mean BOD value } \\
\pm \mathrm{U}_{\mathrm{E}}^{*}\end{array}$ \\
\hline 00 & $\begin{array}{l}\text { National Environmental Quality Standards for } \\
\text { municipal and liquid industrial effluents } \\
\text { into inland water }\end{array}$ & & 80 & \\
\hline 01 & Leh Nullah, Katarian Bridge & 68 & 72 & $70.00 \pm 1.43$ \\
\hline 02 & $\begin{array}{l}\text { Wastewater old slaughter house, near } \\
\text { Ratta Bridge }\end{array}$ & 118 & 124 & $120.00 \pm 2.32$ \\
\hline 03 & City sewage at Ratta Bridge & 208 & 214 & $210.00 \pm 2.34$ \\
\hline 04 & City sewage at Moti Mahal & 298 & 302 & $300.00 \pm 1.51$ \\
\hline 05 & Waste water Leh Nullah at Moti Mahal & 176 & 182 & $180.00 \pm 2.33$ \\
\hline 06 & $\begin{array}{l}\text { Waste water Leh before confluence with } \\
\text { Soan River }\end{array}$ & 76 & 82 & $80.00 \pm 2.34$ \\
\hline 07 & $\begin{array}{l}\text { Soan River } 500 \text { meter upstream of confluence } \\
\text { with Leh Nullah }\end{array}$ & 08 & 12 & $10.00 \pm 1.42$ \\
\hline 08 & $\begin{array}{l}\text { Soan River } 500 \text { meter downstream of } \\
\text { confluence with Leh }\end{array}$ & 18 & 22 & $20.00 \pm 2.34$ \\
\hline 09 & $\begin{array}{l}\text { Soan River near Defense Housing Society } \\
\text { Phase-1 }\end{array}$ & 28 & 32 & $30.00 \pm 1.52$ \\
\hline 10 & Soan River opposite to Dhaghal Village & 27 & 31 & $30.00 \pm 1.52$ \\
\hline 11 & Soan River opposite to Jail & 28 & 32 & $30.00 \pm 1.43$ \\
\hline 12 & Soan River at Road Bridge near Gorakh Pur & 18 & 22 & $20.00 \pm 1.49$ \\
\hline
\end{tabular}

Results are based upon five samples collected from each site.

*The reported expanded uncertainty of measurement is stated as the standard uncertainty of measurement multiplied by the coverage factor $\mathrm{k}=2$, which for a normal distribution corresponds to a coverage probability of approximately $95 \%$.

Table 6. Chemical Oxygen Demand (COD) in water samples

\begin{tabular}{|c|c|c|c|c|}
\hline $\begin{array}{l}\text { Site } \\
\text { no. }\end{array}$ & Sampling site / location & $\begin{array}{l}\text { Minimum COD } \\
\text { value }(\mathrm{ppm})\end{array}$ & $\begin{array}{l}\text { Maximum COD } \\
\text { value }(\mathrm{ppm})\end{array}$ & $\begin{array}{l}\text { Mean COD value } \\
\pm \mathrm{U}_{\mathrm{E}}^{*}\end{array}$ \\
\hline 00 & $\begin{array}{l}\text { National Environmental Quality Standards for } \\
\text { municipal and liquid industrial effluents } \\
\text { into inland water }\end{array}$ & & 150 & \\
\hline 01 & Leh Nullah, Katarian Bridge & 74 & 77 & $75.60 \pm 1.02$ \\
\hline 02 & $\begin{array}{l}\text { Wastewater old slaughter house, near } \\
\text { Ratta Bridge }\end{array}$ & 169 & 179 & $175.20 \pm 4.85$ \\
\hline 03 & City sewage at Ratta Bridge & 169 & 180 & $174.60 \pm 4.86$ \\
\hline 04 & City sewage at Moti Mahal & 308 & 319 & $313.44 \pm 4.84$ \\
\hline 05 & Waste water Leh Nullah at Moti Mahal & 228 & 238 & $232.16 \pm 4.86$ \\
\hline 06 & $\begin{array}{l}\text { Waste water Leh before confluence with } \\
\text { Soan River }\end{array}$ & 119 & 129 & $120.80 \pm 3.97$ \\
\hline 07 & $\begin{array}{l}\text { Soan River } 500 \text { meter upstream of confluence } \\
\text { with Leh Nullah }\end{array}$ & 12 & 13 & $12.30 \pm 0.37$ \\
\hline 08 & $\begin{array}{l}\text { Soan River } 500 \text { meter downstream of } \\
\text { confluence with Leh }\end{array}$ & 32 & 34 & $32.80 \pm 0.75$ \\
\hline 09 & $\begin{array}{l}\text { Soan River near Defense Housing Society } \\
\text { Phase-1 }\end{array}$ & 62 & 66 & $64.00 \pm 1.42$ \\
\hline 10 & Soan River opposite to Dhaghal Village & 115 & 117 & $116.00 \pm 0.89$ \\
\hline 11 & Soan River opposite to Jail & 120 & 122 & $120.00 \pm 0.63$ \\
\hline 12 & Soan River at Road Bridge near Gorakh Pur & 71 & 74 & $72.40 \pm 1.20$ \\
\hline
\end{tabular}

Results are based upon five samples collected from each site.

*The reported expanded uncertainty of measurement is stated as the standard uncertainty of measurement multiplied by the coverage factor $\mathrm{k}=2$, which for a normal distribution corresponds to a coverage probability of approximately $95 \%$. 
Village, Jail and Gorakhpur Village might be due to further addition of sewage waste from nearby population and agricultural runoff.

Total suspended solids (TSS). An average level of total suspended solids of Soan River water had increased with the addition of Leh Nullah waste from $1.44 \pm 0.29$ to $15.20 \pm 0.98 \mathrm{ppm}$. However, TSS values were within NEQS limits (NEQS, 2000).

Total dissolved solids (TDS). An average level of total dissolved solids of Soan River water had increased with the addition of Leh Nullah waste from $169.60 \pm 2.87$ to $550.00 \pm 2.87 \mathrm{ppm}$. TDS values were within NEQS limits (NEQS, 2000).

\section{Conclusion}

Although partial treatment is given to the sewage of Islamabad before it is drained out into Leh Nullah, but untreated sewage of Rawalpindi is causing an increase in BOD, COD, TSS and TDS of Soan River water, which is an alarming sign. By taking following measures, Soan River water quality can be restored:

i. Rawalpindi Municipal Corporation (RMC), Rawalpindi Development Authority (RDA), Capital Development Authority (CDA), Rawalpindi Cantonment Board (RCB), Military Engineering Services (MES) and other responsible agencies should work in close collaboration for proper implementation of environmental improvement projects to improve environmental conditions of the water bodies.

ii. Wastewater treatment facilities should be increased. Installation of new wastewater treatment plant, and restoration of present plants be ensured for $100 \%$ treatment of liquid waste generated in Rawalpindi and Islamabad.

iii. Existing sewerage disposal facilities be improved and provision of new ones be made where no such facilities exist to encourage people to throw their waste properly.

iv. Installation of incinerators in Rawalpindi hospitals to prevent them from throwing life threatening infected waste into Leh Nullah and Soan River.

v. Controlling the problem of industrial pollution through strict implementation of National Environmental Quality Standards (NEQS) and other regulatory mechanism. Increasing pollution of Soan River is endangering aquatic life of the river, therefore, regular monitoring of Soan River water must be planned.

\section{References}

Ahmed, K., Ali, W. 2000. Evaluation of Ravi river quality. Journal of Drainage and Water Management, 4: 27-35.

Ajibade, W.A., Ayodele, I.A., Agbede, S.A. 2008. Water quality parameters in major rivers of Kainji Lake National Park, Nigeria. African Journal of Environmental Science and Technology, 2: 185-196.

Clesceri, L.S., Greenberg, A.E., Eaton, A.D. (eds.) 1998. AWWA/APHA/WEF, Standard Methods for the Examination of Water \& Wastewater, $20^{\text {th }}$ edition, Washington DC, USA.

Holden, W.S. 1970. Water Treatment and Examination, 179 pp., J. \& A. Churchill 104, Gloucester Place, London, UK.

Issac, A., John, D., Elizabeth, M. 1996. Concise Science Dictionary, 546 pp., $3^{\text {rd }}$ edition, Oxford University Press, Oxford, New York, USA.

Kolo, B.G., Ogugbuaja, V.O., Dauda, M. 2010. Seasonal variation in dissolved oxygen and organic pollution indicators of Lake Chad Basin area of Borno State, Nigeria. Continental Journal of Applied Sciences, 1: $1-5$.

LCCI, 2002. Environmental Pollution Report, Lahore Chamber of Commerce \& Industry Lahore, Pakistan.

NEQS, 2000. National Environmental Quality Standards for Municipal and Liquid Industrial Effluents, pp. 1290-1294, Ministry of Environment. The Gazette of Pakistan.

PNCS, 1991. Pakistan National Conservation Strategy, 79 pp., Ministry of Environment, Government of Pakistan.

Rizvi, M. 1996. The News International, October 5, 11 pp., Pakistan.

Sajjad, M. 2005. Economical solution for the industrial waste problem of Karachi industrial area, In: Proceedings of First International Conference on Environmentally Sustainable Development, vol.2, 845 pp., COMSATS Institute of Information Technology, CIIT, Abbotabad, Pakistan.

Sarwar, M.I., Majumder, A.K., Islam, M.N. 2010. Water quality parameters: A case study of Karnafully River Chittagong, Bangladesh. Bangladesh Journal of Scientific and Industrial Research, 45: 177-181.

Sheikh, A.T. 1998. Ecology and pollution in human Settlements: Nala Leh. 5 pp., LEAD, Pakistan.

The World Bank 1992. World Development Report, 47 pp., Oxford, UK.

van Dijk, I. A., Hussein, M.H. 1994. Environmental Profile of NWFP, Pakistan, DHV Consultants BV, Amersfoort, The Netherlands/EDC (Pvt.) Limited, Enterprise \& Development Consulting, Islamabad, Pakistan. 